\title{
Faktor-faktor yang berhubungan dengan kejadian infeksi saluran pernapasan akut (ISPA) pada pekerja PT.X
}

\author{
Muhammad Yunus, ${ }^{1, *}$, Widi Raharjo ${ }^{2}$, Agus Fitriangga ${ }^{2}$ \\ ${ }^{1}$ Program Studi Kedokteran, Fakultas Kedokteran Universitas Tanjungpura, Kalimantan Barat, Indonesia \\ 2 Departemen Kedokteran Komunitas, Fakultas Kedokteran Universitas Tanjungpura, Kalimantan Barat, Indonesia \\ * Korespondensi: nunusyunus25@gmail.com
}

\begin{abstract}
Abstrak
Latar belakang: Infeksi saluran pernapasan akut (ISPA) adalah penyakit saluran pernapasan atas atau bawah, dimulai dari hidung sampai ke alveoli, dapat menular, dan juga dapat menimbulkan berbagai spektrum penyakit berkisar dari tanpa gejala atau infeksi ringan sampai penyakit parah dan mematikan, tergantung patogen penyebab, faktor lingkungan, dan faktor pejamu. Infeksi saluran pernapasan akut dapat disebabkan oleh bakteri, virus, jamur dan polusi udara yang menjadi sumber infeksi pada bagian saluran pernapasan. Penelitian ini bertujuan untuk mengetahui faktor -faktor yang berhubungan dengan kejadian infeksi saluran pernapasan akut di PT. X. Metode: Penelitian analitik observasional dengan pendekatan cross-sectional. Jumlah sampel 43 orang. Hasil: Determinan kejadian ISPA adalah usia $(\mathrm{p}=0,001)$, jenis kelamin $(\mathrm{p}=1,000)$, pengetahuan $(\mathrm{p}=0,004)$, pendidikan $(\mathrm{p}=0,023)$, masa kerja $(\mathrm{p}=0,745)$, fasilitas kesehatan $(\mathrm{p}=0,535)$, penggunaan APD $(\mathrm{p}=0,032)$, peran petugas kesehatan $(\mathrm{p}=0,116)$, peran petugas $\mathrm{K} 3(\mathrm{p}=1,000)$. Analisis multivariat menghasilkan determinan usia $(\mathrm{p}=0,002)$, dan pengetahuan $(\mathrm{p}=0,028)$. Kesimpulan: Terdapat hubungan antara usia, pengetahuan, pendidikan, dan penggunaan APD dengan kejadian ISPA pada pekerja PT. X. Variabel yang paling berpengaruh adalah usia, dan pengetahuan.
\end{abstract}

Kata kunci: ISPA, pekerja, APD

\section{Factors related to acute respiratory infection (ARI) incidence among workers at PT.X}

\begin{abstract}
Background: Acute respiratory infections (ARI) are upper or lower respiratory tract diseases, starting from the nose to the alveoli, can be contagious and cause a variety of diseases ranging from asymptomatic or mild infections to severe and deadly diseases, depending on the causative pathogen, environmental, and host factors. ARI can be caused by bacteria, viruses, fungi and air pollution which are source of infection in the respiratory tract. The aim of this study is to investigate factors related to the occurence of acute respiratory infection (ARI) among workers at X Inc. Methods: This studywas an observational analytic research with cross-sectional design. Total sample was 43 respondents. Independent variables were age, sex, knowledge, education, years of work, health facilities, self-protection tools usage, role of health personnels and role of safety and health officers. Results: Determinants for acute respiratory infection (ARI) were: age $(p=0,001)$, sex $(p=1,000)$, knowledge $(p=0,004)$, education $(p=0,023)$, work length $(p=0,745)$, health facilities $(p=0.535)$, self-protection tools usage $(\mathrm{p}=0,032)$, role of health personnels $(\mathrm{p}=0,116)$, role of safety officers $(\mathrm{p}=1,000)$. Multivariate analysis showed the most important factors were age $(\mathrm{sig}=0,002)$ and knowledge $(\mathrm{sig}=0,028)$. Conclusions. There is correlations between age, knowledge, education, and self-protection tools usage with the occurence of acute respiratory infection among workers at $\mathrm{X}$, Inc. The most important variables are age and knowledge.
\end{abstract}

Keywords: ARI (acute respiratory infection), workers, self-protection tools usage 


\section{Pendahuluan}

Infeksi saluran pernapasan akut merupakan penyakit saluran pernafasan pada bagian atas maupun bawah, dimulai dari hidung sampai ke alveoli, dapat menular, dan juga bisa menyebabkan spektrum penyakit dimulai dari tidak ada gejala maupun infeksi yang ringan hingga infeksi berat yang menimbulkan penyakit parah maupun kematian, bergantung pada patogen penyebab, faktor lingkungan, dan juga faktor pendukung lainnya. $^{1,2}$ Infeksi saluran pernapasan yang akut merupakan satu diantara penyakit yang tinggi terjadi di Indonesia. ${ }^{3}$

Risiko infeksi saluran pernapasan akut tergolong tinggi terutama oleh pekerja di bidang industri yang terdapat risiko dan bahaya yang bersumber dari manusia, alat kerja, mesin dan material-material lainnya. ${ }^{4}$ Data International Labour Organization (ILO) (2013) menjelaskan satu diantara penyebab kematian yang ada hubungannya dengan pekerjaan di antaranya seperti kanker dengan kasus 34\%, kecelakaan $25 \%$, peyakit pada saluran pernapasan $21 \%$, penyakit kardiovaskular $15 \%$, dan beberapa faktor lainnya 5\%. ${ }^{5}$ Pekerja yang terpapar oleh debu mempunyai risiko terkait masalah kesehatan maupun penyakit infeksi, dan non infeksi.

Pengolahan kayu di pabrik mebel menghasilkan serbuk kayu dan sumber bahaya kesehatan lainnya termasuk bahan kimia, bakteri dan jamur. ${ }^{6}$ Masalah mengenai pernapasan merupakan permasalahan terbanyak yang ada di industri kayu. ${ }^{7}$ Pekerja industri kayu berisiko menderita ISPA karena terpapar langsung debu-debu yang melayang di udara yang berasal dari kayu dan masuk ke saluran pernapasan melalui tarikan nafas. ${ }^{6,8}$ Sistem pernapasan adalah sistem tubuh pertama yang dirugikan oleh debu. Paparan debu dapat mengiritasi sistem pernapasan, merusak jaringan saluran napas, membuat jaringan fibrotik dan merusak fungsi saluran napas. ${ }^{9,10}$ Jaringan saluran napas yang telah terpapar debu kayu akan menjadi sangat rentan terinfeksi oleh agen yang juga terdapat pada debu kayu maupun di lingkungan kerja. ${ }^{11}$

PT. X adalah perusahaan jasa industri kayu lapis di Kabupaten Kubu Raya Kalimantan Barat. Studi pendahuluan menggunakan metode HIRA (Hazard Identification and Risk Assessment) mendapatkan potensi bahaya kesehatan tinggi pada tenaga kerja di lapangan, baik yang berdampak langsung maupun dalam jangka panjang. Dampak risiko tersebut di antaranya ISPA, nyeri punggung bawah, gangguan penglihatan, konjungtivitis, iritasi mata dan kulit, dan gangguan pendengaran. Di antara risiko-risiko tersebut, yang paling tinggi adalah paparan debu yang akan berdampak dan menyebabkan penyakit ISPA. ${ }^{12}$ Pada penelitian ini diambil sampel pekerja bidang sander (kegiatan amplas kayu lapis) karena bagian ini langsung berhadapan dan menghasilkan debu-debu halus dari hasil pengamplasan kayu lapis. Hingga saat ini belum terdapat penelitian mengenai faktor-faktor yang berhubungan dengan kejadian ISPA pada pekerja bagian sander di PT. X.

\section{Metode}

Penelitian bersifat survei analitik melalui cara potong-lintang, merupakan penelitian untuk mengetahui berbagai dinamika dan korelasi pada faktor-faktor risiko dan efek menggunakan cara pendekatan, observasi maupun pengambilan dan pengumpulan data yang diambil dalam satu waktu. ${ }^{15}$ Penelitian dilakukan di wilayah kerja PT. X, Kecamatan Sungai Raya, Kabupaten Kubu Raya, Kalimantan Barat. Penelitian dilakukan dengan rentang waktu Januari 2019 sampai dengan Oktober 2019.

Kriteria inklusi penelitian ini adalah pekerja produksi bagian sander, bersedia menjadi responden dan bukan perokok aktif. Kriteria eksklusi adalah perokok aktif dan/atau tidak hadir pada saat penelitian. Sampel dipilih dengan cara probability sampling menggunakan rumus Lameshow, dan didapatkan jumlah sampel sesuai kriteria sebanyak 43 responden. Instrumen yang digunakan pada penelitian ini merupakan lembar kuesioner. Pengetahuan definisi, penyebab, tatalaksana, penularan dan pencegahan ISPA, pengetahuan dianggap baik jika nilainya lebih dari $75 \%$ total nilai.

\section{Hasil}

\section{Analisis univariat}

Hasil analisis univariat dapat dilihat pada Tabel 
Tabel. 1 Karakteristik responden

\begin{tabular}{|c|c|c|c|}
\hline Variabel & Kategori & Frekuensi (n) & $\%$ \\
\hline \multirow[t]{3}{*}{ Usia } & $>45$ Tahun & 4 & 9,3 \\
\hline & 26-45 Tahun & 28 & 65,1 \\
\hline & 17-25 Tahun & 11 & 25,6 \\
\hline \multirow[t]{2}{*}{ Jenis Kelamin } & Laki - laki & 2 & 4,7 \\
\hline & Perempuan & 41 & 95,3 \\
\hline \multirow[t]{3}{*}{ Pengetahuan } & Kurang & 12 & 27,9 \\
\hline & Cukup & 19 & 44,2 \\
\hline & Baik & 12 & 27,9 \\
\hline \multirow[t]{2}{*}{ Pendidikan } & SD dan SMP sederajat & 20 & 46.5 \\
\hline & SMA dan Pendidikan Tinggi (PT) & 23 & 53,5 \\
\hline \multirow[t]{2}{*}{ Masa Kerja } & $\geq 5$ Tahun & 26 & 60,5 \\
\hline & $<5$ Tahun & 17 & 39,5 \\
\hline \multirow[t]{2}{*}{ Fasilitas Kesehatan } & Tidak lengkap & 2 & 4,7 \\
\hline & Lengkap & 41 & 95,3 \\
\hline \multirow[t]{4}{*}{ Penggunaan APD } & Tidak pernah & 2 & 4,7 \\
\hline & Jarang & 4 & 9,3 \\
\hline & Kadang - Kadang & 18 & 41,9 \\
\hline & Selalu & 19 & 44,2 \\
\hline \multirow[t]{2}{*}{ Peran Petugas kesehatan } & Tidak ada & 2 & 4,7 \\
\hline & Ada & 41 & 95,3 \\
\hline \multirow[t]{2}{*}{ Peran Petugas K3 } & Tidak ada & 3 & 7 \\
\hline & Ada & 40 & 93 \\
\hline \multirow[t]{2}{*}{ Kejadian ISPA } & Pernah & 28 & 65,1 \\
\hline & Tidak Pernah & 15 & 34,9 \\
\hline
\end{tabular}

\section{Analisis bivariat}

Tabel 2. Hasil analisis bivariat

\begin{tabular}{|c|c|c|c|c|}
\hline \multirow{2}{*}{ Variabel } & \multirow{2}{*}{ Kategori } & \multicolumn{2}{|c|}{ Kejadian ISPA } & \multirow{2}{*}{$\mathrm{P}$ value } \\
\hline & & Pernah $(\%)$ & Tidak Pernah (\%) & \\
\hline \multirow[t]{3}{*}{ Usia (tahun) } & $>45$ & $3(7)$ & $1(25)$ & 0,001 \\
\hline & $25-45$ & $23(82,1)$ & $5(17,9)$ & \\
\hline & $17-45$ & $2(18,2)$ & $9(81,8)$ & \\
\hline \multirow[t]{2}{*}{ Jenis kelamin } & Laki-laki & $1(50)$ & $1(50)$ & 1,000 \\
\hline & Perempuan & $27(65,8)$ & $14(34,2)$ & \\
\hline \multirow[t]{3}{*}{ Pengetahuan } & Kurang & $10(83,3)$ & $2(16,7)$ & 0,004 \\
\hline & Cukup & $15(78,9)$ & $4(21,1)$ & \\
\hline & Baik & $3(25)$ & $9(75)$ & \\
\hline \multirow[t]{2}{*}{ Pendidikan } & SD dan SMP & $17(85)$ & $3(15)$ & 0,023 \\
\hline & SMA dan PT & $11(47,8)$ & $12(52,2)$ & \\
\hline \multirow[t]{2}{*}{ Masa Kerja } & $\geq 5$ tahun & $16(61,5)$ & $10(38,5)$ & 0,745 \\
\hline & $<5$ tahun & $12(70,6)$ & $5(29,4)$ & \\
\hline \multirow[t]{2}{*}{ Fasilitas kesehatan } & Tidak lengkap & $2(100)$ & $0(0,0)$ & 0,535 \\
\hline & Lengkap & $26(63,4)$ & $15(36,6)$ & \\
\hline \multirow[t]{4}{*}{ Penggunaan APD } & Tidak pernah & $2(100)$ & $0(0,0)$ & 0,032 \\
\hline & Jarang & $3(75)$ & $1(25)$ & \\
\hline & Kadan- kadang & $15(83,3)$ & $3(16,7)$ & \\
\hline & Selalu & $8(42,1)$ & $11(57,9)$ & \\
\hline \multirow[t]{2}{*}{ Peran Petugas kesehatan } & Tidak ada & $0(0,0)$ & $2(100)$ & 0,116 \\
\hline & Ada & $28(68,3)$ & $13(31,7)$ & \\
\hline \multirow[t]{2}{*}{ Peran Petugas K3 } & Tidak ada & $2(66,7)$ & $1(33,3)$ & 1,000 \\
\hline & Ada & $26(65)$ & $14(35)$ & \\
\hline
\end{tabular}




\section{Seleksi bivariat}

Tabel 3. Uji seleksi bivariat

\begin{tabular}{lcc}
\multicolumn{1}{c}{ Variabel } & P value & Keterangan \\
\hline Usia & 0,001 & Kandidat \\
Pengetahuan & 0,004 & Kandidat \\
Pendidikan & 0,023 & Kandidat \\
Penggunaan APD & 0,032 & Kandidat \\
\hline
\end{tabular}

Bila hasil analisis antara bivariat dengan variabel bebas dan variabel terikat menghasilkan $\mathrm{P}<0,25$, maka variabel bebas tersebut dimasukkan ke dalam tahap analisis multivariat.

\section{Analisis multivariat}

Tabel 4. Pemodelan multivariat

\begin{tabular}{lcccc}
\hline \multirow{2}{*}{ Variabel } & \multirow{2}{*}{ Sig. } & \multirow{2}{*}{$\begin{array}{c}\text { Exp } \\
(B)\end{array}$} & \multicolumn{2}{c}{ 95\% C.I.for EXP(B) } \\
\cline { 4 - 5 } & & Lower & Upper \\
\hline Usia & .004 & 8.982 & 2.010 & 40.148 \\
\hline Usia & .020 & 6.525 & 1.348 & 31.581 \\
Pengetahuan & .028 & 3.621 & 1.148 & 11.415 \\
\hline
\end{tabular}

\section{Pembahasan}

\section{Analisis univariat}

Didapatkan responden terbanyak perempuan berumur 28-45 tahun, karena PT. X memprioritaskan pekerja lapangan berusia muda dan bagian plywood hanya merekrut/mencari pekerja perempuan. Tingkat pengetahuan responden mengenai ISPA menunjukkan sebagian besar tingkat pengetahuan responden adalah kategori cukup. Rata-rata responden berpendidikan SMA dan PT karena PT. X meningkatkan persyaratan minimal tamatan SMA.

Berdasarkan masa kerja, didapatkan responden dominan masa kerja $\geq 5$ tahun, secara teoritis apabila masa kerja tergolong lama, akan terdapat akumulasi debu halus kayu hasil buangan kayu lapis tersebut. ${ }^{13}$

Pada bagian fasilitas kesehatan, dominan responden berpendapat lengkap, karena para petugas K3 selalu mengingatkan para pekerja untuk mengunjungi klinik perusahaan jika merasa tidak sehat; di klinik perusahaan terdapat fasilitas klinik kesehatan yang cukup baik seperti ruang periksa pasien dan alat-alat kesehatan (kursi, meja periksa, bed, dan alat-alat kedokteran). Penggunaan APD responden tergolong masih belum disiplin, rata-rata hanya kadang-kadang menggunakan APD dan masih banyak yang jarang dan tidak menggunakan APD dapat berkaitan dengan minimnya pengetahuan dan kesadaran individu, dan masih banyak responden beranggapan APD dipakai jika sudah sakit saja. Rata-rata responden berpendapat ada peran petugas kesehatan, petugas kesehatan memberi sosialisasi dan monitoring pekerjaan saat jam kerja karena pada saat tersebut seluruh pekerja berkumpul di satu halaman untuk diberikan sosialisasi kesehatan. Pada bagian sander terdapat pekerja-pekerja yang tentu juga terlibat dan menjadi target petugas kesehatan menjalankan fungsinya. Para pekerja yang diteliti merasakan ada peran dari petugas kesehatan. Pada dasarnya, peran petugas kesehatan bekerjasama dengan petugas $\mathrm{K} 3$ perusahaan PT. X, petugas K3 juga mengawasi, dan memperingatkan para pekerja terutama pentingnya menjaga kesehatan dalam bekerja. Responden dominan menjawab adanya peran dari petugas K3 perusahaan PT. X.

Berdasarkan kejadian ISPA, 65,1\% dari 43 responden pernah mengalami ISPA.

\section{Hubungan usia dengan kejadian ISPA}

Usia adalah perhitungan umur dari masa dilahirkan sampai akan berulang tahun. Makin cukup usia seseorang, maka seseorang akan lebih matang pada saat berpikir dan bekerja bekerja. ${ }^{14}$ Usia merupakan salah satu faktor predisposisi pembentuk sikap dan perilaku seseorang. ${ }^{15}$

Pada penelitian ini diperoleh nilai $\mathrm{P}=0,001$ berarti terdapat hubungan signifikan antara usia dan kejadian ISPA. Penelitian Sebates ${ }^{16}$ menunjukkan umur seseorang mempengaruhi pola pikir dan daya tangkap orang tersebut. Semakin usia bertambah maka akan semakin berkembang pula pola pikir dan daya tangkapnya, maka pengetahuan yang diperolehnya semakin membaik. Penelitian ini sejalan dengan penelitian Ibnu ${ }^{17}$ bahwa didapatkan hubungan antara usia dengan kejadian ISPA pada pekerja yang terpapar debu kayu. Prasetyo ${ }^{18}$ menunjukkan bahwa kapasitas difusi paru, ventilasi paru, ambilan oksigen kapasitas vital dan semua parameter faal paru lain akan menurun sesuai pertambahan umur sehingga makin lanjut usia akan makin rentan terkena ISPA.

\section{Hubungan jenis kelamin dengan kejadian ISPA}

Jenis kelamin adalah identitas gender seseorang. Jenis kelamin merupakan salah satu faktor predisposisi pembentuk sikap dan perilaku. ${ }^{15}$ Pada penelitian yang dilakukan diperoleh nilai $\mathrm{P}=1,000$ maka tidak terdapat pengaruh antara jenis kelamin 
dan kejadian ISPA.

Menurut penelitian Hidayat $^{19}$ kejadian ISPA lebih banyak terjadi pada laki-laki dan jarang pada perempuan dikarenakan laki-laki cenderung lebih aktif dibanding perempuan. Raina ${ }^{20}$ juga mendapatkan ISPA juga lebih sering pada laki-laki dengan alasan yang sama. Berdasarkan teori memang demikian, akan tetapi hasil tersebut beda dengan penelitian yang dilakukan ini dikarenakan sampel/responden penelitian ini kebanyakan perempuan, sehingga tidak didapatkan hubungan yang relevan.

\section{Hubungan tingkat pengetahuan dengan kejadian ISPA}

Pengetahuan merupakan hasil tahu dan dapat menjadi tahu apabila seseorang telah melakukan penginderaan pada suatu objek tertentu; perilaku yang didasari pengetahuan akan lebih bertahan lama daripada tindakan yang tidak berdasarkan pengetahuan. $^{21}$ Pengetahuan menjadi satu diantara beberapa faktor pembentuh sikap maupun prilaku dari seseorang. ${ }^{15}$ Pada hasil penelitian diperoleh nilai $\mathrm{P}=0,004$ bahwa didapatkan hubungan tingkatan pengetahuan dengan kejadian ISPA. Mengetahui bahwa diri sendiri berisiko terkena ISPA akan meningkatkan kesadaran responden untuk mencegah ISPA. Risiko ISPA responden melalui lingkungan pekerjaan berasal dari debu halus kayu.

Berdasarkan penelitian Wardhani ${ }^{22}$, tingkat pengetahuan sangat berpengaruh dengan kejadian ISPA; berbagai macam faktor-faktor seperti tingkatan pendidikan, peran dari penyuluhan kesehatan, informasi yang dapat diakses melalui media, dan keinginan untuk mengetahui tentang kejadian ISPA juga berdasarkan tingkatan dari pengetahuan. Hasil yang didapat dari penelitian tersebut sejalan dengan hasil yang diperoleh dari penelitian ini bahwa terdapat hubungan dari tingkat pengetahuan dengan kejadian ISPA. Namun Kusnanto $^{23}$ tidak mendapatkan hubungan signifikan antara pengetahuan dengan ISPA dengan alasan karena perilaku seseorang tidak selalu berhubungan dengan pengetahuan, dan juga disebutkan bahwa yang mempengaruhi pengetahuan adalah pengalaman pribadi, kondisi lingkungan fisik maupun non-fisik, pengetahuan tentang sosial budaya, persepsi dan keyakinan yang berujung melakukan sebuah tindakan. Pengaruh variabel lain seperti tidak sejalannya lingkungan sekitar dengan persepsi atau pengetahuan pribadi, dapat memengaruhi keputusan untuk melakukan apa yang mereka ketahui.

Billy $^{24}$ mendapatkan bahwa pada pekerja batu bata, pengetahuan berhubungan dengan kejadian ISPA $(\mathrm{P}=0,041)$, sejalan dengan penelitian ini, bahwa tingginya pengetahuan mengenai kesehatan dan lingkungan sekitar, dapat menjadi pengetahuan mengenai upaya dalam perlindungan diri.

\section{Hubungan tingkat pendidikan dengan kejadian ISPA}

Pendidikan merupakan satu diantara faktor yang membentuk sikap dan perilaku seseorang karena pendidikan dasar pribadi sebagai penunjang orang berpikir secara logis juga rasional, persepsi dari berbagai sisi untuk menganalisis dan menyelesaikan suatu masalah ${ }^{15}$. Motivasi seseorang dapat dipengaruhi oleh pendidikan. Seseorang dengan motivasi tinggi dapat lebih serius untuk penerapan pola hidup yang sehat. ${ }^{19}$ Pada hasil penelitian ini diperoleh hubungan terkait tingkatan pendidikan dan kejadian ISPA $(\mathrm{P}=0,023)$.

Julianty $^{25}$ menyebutkan bahwa terdapat hubungan yang baik antara pendidikan dan kesehatan.Hasil didapatkan setelah melakukan kontrol mengenai variable pengetahuan dengan perilaku dan kesehatan lingkungan. Hal tersebut sesuai dengan hasil penelitian ini yaitu didapatkan hubungan terkait tingkatan pendidikan dan kejadian ISPA, makin tinggi pendidikan maka akan makin sedikit terkena ISPA

Habibi $^{26}$ mendapatkan hasil $84,8 \%$ responden berpendidikan rendah yang mengidap ISPA; pendidikan dapat berpengaruh terhadap tindakan pencegahan karena pendidikan mempengaruhi kemampuan individu untuk paham terhadap informasi tentang kesehatan. Hal tersebut berdampak pada individu untuk lebih memperhatikandan lebih sigap dalam melakukan pencegahan penyakit.

\section{Hubungan masa kerja dengan kejadian ISPA}

Pekerja yang berada pada lingkungan kadar debu tinggi dengan waktu yang lama akan memiliki risiko tinggi mengidap penyakit ISPA. ${ }^{27}$ Masa kerja dapat cenderung menjadi satu diantara faktor risiko obstruksi yang terjadi pada pekerja lebih dari 5 tahun di industri berdebu. ${ }^{27}$ Pada penelitian tidak didapatkan hubungan mengenai masa kerja dan kejadian ISPA dengan nilai $(\mathrm{P}=0,745)$.

Khumaidah $^{13}$ menunjukkan terdapat hubungan 
antara masa kerja pekerja dengan gangguan fungsi paru dengan nilai $(\mathrm{p}=0,002)$. karena pada dasarnya lama paparan seseorang dipengaruhi oleh masa kerja yang menjadi satu diantara faktor risiko terhirup debu kayu. Makin lama waktu masa kerja seseorang, maka risiko terkena penyakit paru makin besar. ${ }^{28}$ Hal tersebut tidak sesuai dengan penelitian karena tidak mendapatkan hubungan terkait masa kerja dengan kejadian ISPA. Karena, hal tersebut tetap didasari oleh sistem imun atau sistem kekebalan perorangan dari para pekerja yang berfungsi untuk pertahanan terhadap organisme-organisme luar oleh sel imun yang akan membunuh patogen melalui respons imun yang kolektif terkoordinasi (respons imun). Respons imun seperti mikroorganisme yang masuk ke dalam saluran pernapasan sehingga mempengaruhi silia untuk bergerak ke atas dan mendorong keluar mikroorganisme ke arah faring dengan cara tangkapan reflex spasmus dari laring. Respons itu tergantung pada status imunitas responden pada saat menghirup udara yang disertai pengaruh biologis luar tersebut, apakah berhasil atau tidak. ${ }^{29}$ Berdasarkan hal tersebut, didapatkan alasan mengapa tidak sejalan adalah karena walaupun para pekerja lama terpapar dengan faktor biologis luar (debu kayu) akan tetapi hal tersebut tetap bergantung pada faktor imunitas para pekerja saat itu, apabila imunitas baik maka akan lebih mudah untuk terhindar dari penyakit ISPA yang dikarenakan faktor biologis luar.

Menurut penelitian Billy ${ }^{25}$ dengan nilai $\mathrm{P}=0,026$ bahwa terdapat hubungan yang signifikan antara masa kerja dan kejadian ISPA, risiko terkena penyakit ISPA tinggi terjadi pada pekerja dengan masa kerja lebih dari 5 tahun. Paparan debu dan cemaran dari lingkungan dapat terjadi pada saat pertama kali berkerja, faktor yang terjadi yaitu cemaran dari bahan kimia, debu dan asap, yang berarti masa kerja akan berhubungan erat dengan masuknya cemaran udara atau paparan debu tersebut ke dalam saluran pernapasan. Dampak yang terjadi adalah ketika debu yang masuk pada saluran pernapasan akan terakumulasi dan berkaitan dengan lamanya masa kerja seseorang dan banyaknya cemaran yang terjadi setiap harinya, juga bergantung pada tindakan pencegahan para pekerja dalam mengurangi jumlah partikel yang telah masuk dan yang akan masuk ke dalam tubuh. Terjadi penurunan fungsi paru yang disebabkan faktor pekerjaan dan lingkungan sekitar, dan juga faktor lainnya. ${ }^{30}$

\section{Hubungan ketersediaan fasilitas kesehatan dengan kejadian ISPA}

Berdasarkan teori Green ${ }^{15}$ yang menyatakan bahwa fasilitas kesehatan merupakan satu diantara faktor pemungkin terbentuknya sikap dan perilaku seseorang. Menurut Kusnanto ${ }^{23}$, penderita ISPA lebih cenderung tidak memanfaatkan fasilitas kesehatan yang tersedia. Ketersediaan fasilitas kesehatan yang lengkap diharapkan akan meningkatkan pelayanan kesehatan bagi masyarakat, akan meningkatkan kemauan dan kepercayaan masyarakat untuk memanfaatkan fasilitas kesehatan. Penelitian ini didapatkan dengan $\mathrm{P}=0,535$ bahwa tidak didapatkan hubungan yang signifikan antara fasilitas kesehatan dan kejadian ISPA.

Berdasarkan penelitian Nova ${ }^{31}$ mengenai tingkat kesediaan dan pemanfaat fasilitas kesehatan, didapatkan bahwa semakin lengkap fasilitas kesehatan, maka akan semakin banyak juga pengunjung yang memanfaatkan fasilitas kesehatan tersebut. Seseorang yang memanfaatkan fasilitas kesehatan dalam rangka untuk memelihara kesehatannya sebelum terkena penyakit itu termasuk ke dalam upaya preventif. ${ }^{32}$ Hasil dari penelitian tersebut tidak sesuai dengan hasil dari penelitian ini dan teori Green $^{15}$, dimana tidak didapatkan hubungan pada fasilitas kesehatan dengan kejadian ISPA, hal tersebut didapatkan demikian karena kurangnya variasi data atau data yang didapat cenderung ke satu jawaban pada saat penelitian dilaksanakan.

\section{Hubungan penggunaan APD dengan kejadian ISPA}

Sesuai dengan teori Green ${ }^{15}$ bahwa penggunaan APD merupakan satu diantara pemungkin terbentuknya sikap dan perilaku seseorang maupun sumber daya disertai untuk melaksanakan perilaku. Alat pelindungan diri merupakan alat yang dipakai pekerja guna melindungi tubuh dari potensi terjadinya bahaya dan kecelakaan. Penelitian berikut didapatkan dengan $\mathrm{P}=0,032$ bahwa didapatkan hubungan terkait penggunaan APD dan kejadian ISPA.

Menurut Harry ${ }^{33}$ menyatakan bahwa pentingnya penggunnaan APD sebagai lini pertahanan guna melindungi pengguna dari akibat atau dampak yang dihasilkan oleh kondisi yang tidak dapat diperkirakan. Hasil dari penelitian Harry sejalan dengan penelitian ini dikarenakan hal tersebut menggambarkan kebiasaan responden dalam 
menggunakan APD, dengan rerata responden masih kadang- kadang saja menggunakan APD, bahkan masih ada responden yang tidak pernah menggunakan APD.

Menurut hasil dari penelitian Khumaidah $^{13}$ didapatkan $\mathrm{P}=0,002$ bahwa terdapat hubungan terkait penggunaan APD dan kejadian ISPA. Menurut Sihombing ${ }^{34}$ dijelaskan mengenai penggunaan masker oleh pekerja di bagian industri dengan kondisi lingkungan yang banyak debu mengudara merupalkan upaya dari pengurangan partikel yang beresiko masuk ke dalam saluran pernapasan. Penggunaan masker untuk melindungi pekerja dari risiko terjadinya gangguan pernapasan akibat dari paparan udara yang banyak kadar debunya. Pekerja yang terbiasa menggunakan masker akan aman apabila pekerja tersebut berada di lingkungan kerja dengan kadar debu tinggi untuk melindungi kesehatan.

Masker yang digunakan pada responden penelitian ini adalah masker bedah (surgical mask) Menurut Budiono ${ }^{35}$ masker bedah ini fungsinya adalah untuk melindungi dan membantu sistem pernapasan dalam menyaring udara yang dihirup, tidak secara keseluruhan untuk melindungi tubuh akan tetapi dapat mengurangi jumlah dari kadar debu yang mungkin akan masuk ke ssaluran pernapasan. Masker bedah cukup efektif dalam menghalang cairan yang kemungkinan akan terpapar ke mulut dan hidung agar tidak mengontaminasi daerah sekeliling perlindungan, akan tetapi masker bedah ini kurang efektif untuk menyaring partikel atau mikroorganisme yang sangat kecil, untuk pihak perusahaan lebih disarankan menggunakan masker N95. Berdasarkan masker yang digunakan oleh para pekerja juga sesuai dengan satu diantara fungsinya bahwa mengurangi keparahan debu yang terjadi, bahwa didapatkan hubungan antara penggunaan APD dengan ISPA, pekerja yang lebih sering menggunakan masker mendapat tingkat kejadian ISPA lebih rendah

\section{Hubungan peran petugas kesehatan dengan kejadian ISPA}

Hasil penelitian yang dilakukan bahwa tidak terdapat hubungan yang signifikan antara peran petugas kesehatan dengan kejadian ISPA, hal tersebut tidak sejalan dengan teori Green ${ }^{15}$ yang menyebutkan mengenai peran petugas kesehatan merupakan satu diantara faktor penguat pembentuk sikap dan perilaku seseorang. Penelitian ini didapatkan $\mathrm{P}=0,116$ bahwa tidak didapatkan hubungan terkait peran petugas kesehatan dan kejadian ISPA.

Berdasarkan penelitian tentang peran petugas kesehatan dengan kejadian suatu penyakit oleh Yanto $^{36}$, menunjukan hasil jumlah responden yang merasa peran petugas kesehatan masih kurang dan mengidap penyakit sebesar $65,7 \%$ dan responden yang merasa peran petugas kesehatan baik dan mengidap penyakit sebesar 44,8\%. Petugas kesehatan berperan dalam penyuluhan mengenai suatu penyakit dengan menyampaikan dan melakukan pencegahan suatu penyakit, penulusuran lebih lanjut jika muncul suatu kasus mengenai penyakit, menghimbau dna mengajak masyarakat untuk menciptakan lingkungan yang bersih dan sosialisasi mengenai kasus yang ada. Hal berikut akan efektif dan meningkatkan kesehatan apabila para pekerja patuh terhadap himbauan dari petugas kesehatan. $^{36}$ Hasil menunjukkan nilai $\mathrm{P}=0,007$ $(\mathrm{p}<0,005)$ bahwa terdapat hubungan terkait peran petugas kesehatan dan kejadian suatu penyakit.

Menurut penelitian Berta $^{37}$ yang meneliti tentang peran dari petugas kesehatan dan penyakit diare, terkait dengan penelitian berikut mengenai peran petugas kesehatan terhadap suatu penyakit, pada penelitian Berta didapatkan bahwa data $\mathrm{P}=0,001$ bahwa terdapat hubungan terkait peran petugas kesehatan dan terjadinya suatu penyakit. Hal ini tidak sejalan dengan penelitian ini, karena penelitian yang dilakukan menunjukkan hasil bahwa tidak didapatkan hubungan antara peran petugas kesehatan dengan kejadian ISPA. Berdasarkan teori sesuai dengan yang telah dibahas, memang demikian, akan tetapi dikarenakan pada penelitian ini hasil dari data yang didapatkan dari responden lebih dominan menjawab ada peran dari petugas kesehatan dan karena jawaban responden lebih cenderung ke satu jawaban, kurangnya variasi data mengakibatkan tidak didapatkan hubungan yang relevan.

Petugas kesehatan berperan dalam tindakan preventif atau pencegahan suatu penyakit dan melakukan penyuluhan mengenai penyakit, pentingnya menerapkan pola hidup sehat, menelusuri lebih lanjut kasus-kasus penyakit, menghimbau dan mengajak masyarakan menjaga kebersihan lingkungan dan mensosialisasikan penyakit-penyakit yang rentan tergantung kondisi lingkungan. ${ }^{37}$ Peran petugas kesehatan juga dirasa sangat efektif dalam sebuah perusahaan, dimana 
petugas kesehatan tidak perlu susah payah mengumpulkan masyarakat banyak, dan tidak ada kekhawatiran adanya orang yang tidak hadir. Pada dasarnya sebuah perusahaan merupakan bentuk dari suatu kelompok yang tiap para pekerja dan pegawainya akan hadir di saat yang bersamaan dan tempat yang sama. Data yang didapatkan tidak menunjukkan adanya hubungan terkait peran petugas kesehatan dan kejadian ISPA. Berdasarkan data yang didapatkan bahwa dominan responden pada penelitian ini menjawab ada terhadap peran petugas kesehatan, dan tidak didapatkan hubungan dengan kejadian ISPA dikarenakan jawaban responden lebih cenderung ke satu jawaban. Pada dasarnya pekerja yang merasakan adanya peran dari petugas kesehatan lebih rendah terkena ISPA dikarenakan para pekerja dihimbau mengenai kebersihan lingkungan dan berbagai penyakit terkait dengan pekerjaan yang dilakukannya.

\section{Hubungan peran petugas $\mathrm{K} 3$ dengan kejadian ISPA}

Teori Green ${ }^{15}$ menyatakan bahwa peran petugas K3 merupakan satu diantara faktor penguat yang membentuk sikap dan juga perilaku dari seseorang. Sear $^{38}$ juga mengatakan bahwa orang yang terdapat kekuasaan pada suatu lingkungan tertentu secara sah dan mempunyai legalitas berhak untuk memperintahkan aturan yang akan dijalankan bersama. Terdapat banyak peran dari petugas K3 dalam perusahaan, namun pada hal ini yang akan dibahas adalah mengenai peran petugas $\mathrm{K} 3$ dengan spesifikasi dalam meningkatkan motivasi dari para pekerja untuk selalu hidup sehat dengan menggunakan APD, memperingati dan memberi aturan, meningkatkan kesadaran akan pentingnya mencegah terjadinya ISPA. Hasil dari penelitian yang dilakukan dengan $\mathrm{P}=1,000$ bahwa didapatkan nilai signifikansi terjauh dari 0,005 berarti tidak terdapat hubungan terkait peran petugas K3 dan kejadian ISPA.

Menurut Kurniawan ${ }^{39}$, petugas K3 haruslah tegas dalam memperingati para pekerja karena hal tersebut mungkin akan meningkatkan kesadaran dan kebanyakan pekerja hanya akan patuh apabila diawasi oleh petugas K3 yang berpatroli sehingga pekerja melakukan prosedur kerja dengan baik.

Menurut Sutrisno ${ }^{40}$ peran petugas K3 satu diantaranya adalah antisipasi bahaya dan sumber penyakit pada lingkungan kerja terkait kondisi biologi, fisik, dan kimia, serta psikologis pekerja.
Penelitian yang dilakukan oleh Qomariyatus ${ }^{41}$, menunjukkan hasil didapatkan hubungan terkait peran petugas $\mathrm{K} 3$ dan kejadian penyakit paru, dengan nilai $\mathrm{P}=0,013$. Hasil didapatkan signifikan karena pada perusahaan tersebut menerapkan prinsip budaya K3 yang mengembangkan pengetahuan, sikap dan perilaku dan juga pekerja yang inovatif terhadap pengendalian kesehatan. Duma juga melakukan penelitian mengenai $\mathrm{K} 3$ dan penyuluhan K3 dengan penerapan satu tahun efektif guna mengembangkan pengetahuan terhadap budaya K3, akan tetapi hal tersebut belum efektif dalam peningkatan kesehatan para pekerja. Pada dasarnya para pekerja menaati aturan dikarenakan terpaksa mengikuti aturan tersebut, bukan karena para pekerja sadar pentingnya budaya K3, apabila para pekerja sadar pentingnya budaya K3 maka segala prosedur akan dipatuhi secara baik walau tanpa pengawasan dari petugas $\mathrm{K} 3$.

Penelitian ini menunjukkan hasil bahwa tidak didapatkan hubungan terkait peran petugas K3 dan kejadian ISPA pada pekerja PT. X, dimana didapatkan nilai signifikansi terjauh dari angka 0,05 berarti tidak terdapat hubungan antara peran petugas K3 dan kejadian ISPA, hal tersebut didapatkan demikian karena hasil penelitian yang dilakukan mendapat jawaban dari responden dengan variasi jawaban yang kurang dan data cenderung ke satu jawaban, sehingga sulit untuk dianalisis terkait hubungan peran petugas K3 dengan kejadian ISPA. Namun, pada dasarnya pekerja yang merasakan adanya peran petugas $\mathrm{K} 3$ lebih rendah terkena ISPA dikarenakan petugas K3 yang bertugas melakukan pengendalian gangguan kesehatan, pekerja akan dimonitoring terkait dengan kepatuhan mengenai peraturan dan prosedur kerja yang baik seperti selalu menggunakan masker, sehingga pekerja terhindar dari hal yang tidak diinginkan seperti terjadinya penyakit ISPA.

\section{Analisis multivariat}

Penelitian ini menggunakan metode forward dan mendapatkan hasil uji regresi logistik ganda. Analisis multivariat menunjukkan hasil bahwa variabel usia 6,525 kali lebih berpengaruh terhadap kejadian ISPA, bahwa makin tua usia pekerja, makin rentan terserang ISPA. Usia berkaitan pada proses penuaan, yang berarti semakin tua usia orang tersebut maka penurunan fungsi paru makin besar. ${ }^{35}$ Kekuatan yang dimiliki otot mencapai puncak pada usia 20 sampai 40 tahun dengan pengurangan 
sebanyak $20 \%$ apabila telah mencapai usia 40 tahun. Hal ini berkaitan dengan kejadian ISPA karena risiko terjadi infeksi meningkat jika imunitas rendah, kondisi tersebut biasa terjadi pada orang dengan usia tua, dikarenakan rendahnya imunitas maka akan lebih rentan terhadap kejadian infeksi satu diantaranya adalah ISPA. ${ }^{20}$ Hasil yang didapatkan oleh penelitian Yunus $^{42}$ juga mengatakan bahwa peningkatan usia berkaitan dengan peningkatan kerentanan akan terjadinya penyakit, khususnya terjadi gangguan pada saluran pernapasan bagi tenaga kerja.

Variabel pengetahuan 3,621 kali lebih berpengaruh terhadap kejadian ISPA, makin baik pengetahuan pekerja akan makin terhindari dari ISPA. Pengetahuan merupakan satu diantara faktor-faktor predisposisi pembentuk sikap dan perilaku manusia ${ }^{15}$. Lewin ${ }^{43}$ yang juga menyebutkan pengetahuan adalah faktor pembentuk perilaku manusia. Pengetahuan mengenai kesehatan serta lingkungan yang tinggi, akan berkaitan dengan uppaya pencegahan dan perlindungan diri dari bahaya paparan cemaran $^{24}$. Pekerja dengan pengetahuan baik akan menyadari akan penyakit ISPA dan cemaran udara bagi kesehatan. Hasil analisis pengetahuan dengan kejadian ISPA pada pekerja didapatkan hubungan yang signifikan karena pengetahuan yang dimaksud adalah responden mengerti mengenai apa itu ISPA, penyebab, tanda dan gejala ISPA, dan pencegahan terjadi ISPA, semakin baik pengetahuan seseorang maka semakin kecil tingkat kejadian ISPA. Usia berpengaruh terhadap daya ingat dan pola berpikir seseorang, semakin tinggi usia maka akan semakin tinggi juga daya tangkap dan pola berpikirnya, sehingga pengetahuan yang didapatkan orang tersebut maka akan semakin baik. ${ }^{44}$ Fungsi pernapasan berdasarkan usia didapatkan bahwa system pernapasan dan kardiovaskuler akan terus meningkat dari masa kecil dan akan mencapai puncak pada usia 20 sampai 30 tahun, namun akan menurun sesuai dengan pertambahan usia. $^{18}$ Kapasitasi difusi paru-paru, ventilasi paru-paru, muatan oksigen, dan juga segala parameter faal paru-paru serta status imunitas dan elastisitas jaringan akan menurun sesuai dengan pertambahan umur. ${ }^{18}$ Berdasarkan penelitian ini didapatkan bahwa semakin tua seseorang maka semakin rentan terkena ISPA.

\section{Kesimpulan}

Terdapat hubungan antara usia, pengetahuan, pendidikan, dan penggunaan APD dengan kejadian ISPA pada pekerja PT. X. Variabel yang paling berpengaruh adalah usia, dan pengetahuan.

\section{Daftar Pustaka}

1. WHO (World Health Organization). Pencegahan dan Pengendalian Infeksi Saluran Pernapasan Akut (ARI) yang Cenderung Menjadi Epidemi dan Pandemi di Fasilitas Pelayanan Kesehatan. Jenewa: WHO; 2007.

2. Habeahan EM. Hubungan Peran Orang Tua dalam Pencegahan Infeksi Saluran pernapasan Akut (ARI) dengan Kekambuhan Infeksi Saluran Pernapasan Akut (ARI) Pada Balita di Wilayah Kerja Puskesmas Martubung [skripsi]. Medan: Universitas Sumatera Utara; 2009.

3. Badan Litbangkes. Laporan Hasil Riset Kesehatan Dasar (RISKESDAS) Nasional. Jakarta: Departemen Kesehatan Republik Indonesia; 2007.

4. Anizar. Teknik Keselamatan dan Kesehatan di Industri. Yogyakarta: Penerbit Graha Ilmu; 2009.

5. ILO (Internatonal Labour Organization). Keselamatan dan Kesehatan Kerja Sarana Untuk Produktivitas. Jakarta: International Labour Office; 2013.

6. Sormin, Kety R. Hubungan Karakteristik dan Perilaku Pekerja yang Terpajan Debu Kapas dengan Kejadian ARI di PT. Unitex Tahun 2011 [skripsi]. Depok: Fakultas Kesehatan Masyarakat Universitas Indonesia; 2012.

7. Rosenberg C, Liukkonen $\mathrm{T}$, Kallas-Tarpila $\mathrm{T}$, Ruonakangas A, Ranta R, Nurminen $M$, et, al. Monoterpene and wood dust exposures: Workrelated symptoms among Finnish sawmill worker. Am J Ind Med 2002;41:(38-53).

8. Sri Maywati, Siti N. Dampak Aktivitas Home Industri Mebel Terhadap Kesehatan Balita di Sekitar Industri Mebel Sektor Informal Kel. Kahuripan Kec. Tawang Kota Tasikmalaya [skripsi]. Tasikmalaya: Fakultas Ilmu Kesehatan Universitas Siliwangi; 2014.

9. Schlunssen V, Schaumburg I, Andersen NT, Sigsgaard T, Pedersen, OF. Nasal patency is related to dust exposure in woodworkers. Occup Environ Med; 2002;9:23-9.8.

10. Bohadana AB, Massin N, Wild P, Toamain JP, Engel $\mathrm{S}$, Goutet, P. Symptoms, airway responsiveness, and exposure to dust in beech and oak wood workers. Occup Env Med 2000;57:268-73.

11. Triatmo Wenang Triatmo, M. Sakundarno Adi, Yusniar, Hanani, D. Paparan Debu Kayu dan Gangguan Fungsi Paru pada Pekerja Mebel (Studi di PT. Alis Jaya Ciptatama). Jurnal Kesehatan Lingkungan Indonesia; 2006;5(2):69-76.

12. Meo S A. Effect of duration of exposure to wood dust on peak expiratory flow rate among workers in small scale wood industries [PubMed]. Int J Occup Med Env Health; 2004;17(4) (451-55).

13. Khumaidah. Analisis Faktor-Faktor yang Berhubungan Dengan Gangguan Fungsi Paru Pada Pekerja Mebel Pt Kota Jati Furnindo Desa Suwawal Kecamatan Mlonggo Kabupaten Jepara [skripsi]. Program Pascasarjana Universitas Diponegoro; 2009. 
14. Notoatmodjo S. Pendidikan dan Perilaku Kesehatan Cetakan 2. Jakarta: PT. Rineka Cipta; 2007.

15. Green L W. Health Education Planning: a diagnostic approach. (1st edition). 1st ed. California: Mayfield Publishing Company; 1980.

16. Sebates, Ricardo, \&, Leon, Feinstein. Education, Training, and the Take-Up of Preventative Health Care. Centre of Research of Wilder Benefit of Learning; 2004.

17. Ibnu Sri Fuqoha. Hubungan Paparan Debu Kayu Dengan Kejadian Infeksi Saluran Pernapasan Akut (ARI) Pada Pekerja Mebel di PT.X Jepara. Jurnal Kesehatan Masyarakat Undip; 2017;5(1).

18. Prasetyo Rawar D. Faktor - Faktor yang Berhubungan dengan Kapasitas Vital Paru pada Pekerja Bengkel Las di Pisangan, Ciputat Tahun 2010 [skripsi]. Jakarta: Universitas Islam Negeri Syarif Hidayatullah; 2010.

19. Hidayat N. Faktor - Faktor yang Berhubungan Dengan Kejadian Penyakit ARI Pada Balita di Kelurahan Paienan Tigo Kecamatan Koto Tengah Kota Padang [skripsi]; 2014.

20. Raina Ulva Amira. Hubungan Status Gizi Dengan Kejadian Infeksi Saluran Pernapasan Akut (ARI) Pada Balita di Wilayah Kerja Puskesmas Siantan Hilir [skripsi]. Fakultas Kedokteran: Untan; 2017.

21. Azwar S. Sikap Manusia dan Pengukurannya. Jakarta: PT Rineka Cipta; 2007.

22. Wardhani, Eka D. Hubungan Faktor Lingkungan, Sosial-Ekonomi, dan Pengetahuan Ibu dengan Kejadian Infeksi Saluran Pernapasan Akut (ARI) pada Balita di Kelurahan Cicadas Kota Bandung. Bandung: Seminar Nasional Sains dan Teknologi. E-Book; 2010.

23. Kusnanto. Hubungan Pengetahuan Dan Sikap Masyarakat Terhadap Tindakan Pencegahan Infeksi Saluran Pernapasan Akut (ARI) Di Desa Tataaran 1 Kecamatan Tondano Selatan Kabupaten Minahasa. Manado: Fakultas Kedokteran Universitas Sam Ratulangi Manado: Jurnal Kedokteran Komunitas dan Tropik; 2016;4(1).

24. Billy Harnaldo Putra. Kajian Hubungan Masa Kerja, Pengetahuan, Kebiasaan Merokok, Dan Penggunaan Masker Dengan Gejala Penyakit ARI Pada Pekerja Pabrik Batu Bata Manggis Gantiang Bukittinggi. Bukittinggi Human Care Jurnal; 2017;2(2):48-54.

25. Julianty Pradono. Hubungan Antara Tingkat Pendidikan, Pengetahuan Tentang Kesehatan Lingkungan, Perilaku Hidup Sehat Dengan Status Kesehatan Studi Korelasi pada Penduduk Umur 10-24 Tahun di Jakarta Pusat. Jakarta Buletin Penelitian Sistem Kesehatan; 2014;17:89-95.

26. Habibi. Faktor-faktor yang Mempengaruhi Kejadian Infeksi Saluran Pernapasan Akut (ARI) pada Anak Berumur 12-59 Bulan di Puskesmas Kelurahan Tebet Barat, Kecamatan Tebet, Jakarta Selatan, Tahun 2013. J Epidemiologi Kesehatan Indonesia Universtiras Indonesia 2016;1:1.

27. RE, Hyatt, Scanlon, M Nakamura. Static (absolute) lung volume, In Interpretation of Pulmonary Function Tes-A Practical Guide. 2nd ed. Philadelphia; 2006.

28. Suma'mur. Hiegiene Perusahaan dan Keselamatan Kerja. Jakarta: CV Agung Seto; 2009.

29. Departemen Kesehatan Republik Indonesia. Direktorat
Jenderal PPM \& PLP. Pedoman Pemberantasan Penyakit Infeksi Saluran Pernapasan Akut (ARI). Jakarta; 1992.

30. Kurniawidjaja LM. Program Perlindungan Kesehatan Respirasi Di Tempat Kerja Manajemen Risiko Penyakit Paru Akibat Kerja. Jurnal Respirologi Indonesia; 2010;30(4):217-29.

31. Nova D. Analisis Pemanfaatan Fasilitas Kesehatan Puskesmas Oleh Masyarakat Di Kecamatan Ngrampal Kabupaten Sragen [skripsi]. Surakarta: Universitas Muhammadiyah Surakarta; 2013.

32. Anhar. Studi Komparatif Pemanfaatan Pelayanan Kesehatan Pada Masyarakat Pedesaan Di Wilayah Kerja Puskesmas Poleang Barat Dengan Masyarakat Perkotaan Di Wilayah Kerja Puskesmas Lepo-Lepo Tahun 2015 [skripsi]. Fakultas Kesehatan Masyarakat Universitas Halu Oleo; 2016.

33. Amin Muhammad. Pengaruh Polusi Udara Terhadap Fungsi Paru. Surabaya: Bagian Pulmonologi: Fakultas Kedokteran Unair, RS Dr Sutomo; 1985;14:6-14.

34. Sihombing T D. Hubungan Kadar Debu Dengan Fungsi Paru Pada Pekerja Proses Press-Packing di Usaha Penampungan Butut Kelurahan Tanjung Mulia Hilir Medan Tahun 2013 [skripsi]. Medan: Universitas Sumatera Utara; 2013.

35. Budiono. AM Sugeng dkk. Bunga Rampai Hiperkes dan Kesehatan. Semarang: Badan Penerbit UNDIP; 2002.

36. Yanto 2012 didalam Berta Afriani. Peran Petugas Kesehatan dan Ketersediaan Sarana Air Bersih dengan Kejadian Diare [skripsi]. Baturaja Aisyah Jurnal Ilmu Kesehatan; 2017;2(2):117-22.

37. Berta Afriani. Peran Petugas Kesehatan dan Ketersediaan Sarana Air Bersih dengan Kejadian Diare. Baturaja Aisyah Jurnal Ilmu Kesehatan; 2017;2(2):117-22.

38. David OS, Jonathan L. Freedman L. Anne P alih bahasa Michael A, Savitri S. Psikologi Sosial. 5th ed. Jakarta: Erlangga; 1994.

39. Wahid Kurniawan. Hubungan Faktor Karakteristik Pekerja, Safety Morning Talk (SMT) dan Housekeeping Dengan Kejadian Minor Injury Pada Pekerja di Proyek Pembangunan Gedung Kantor PT. $\mathrm{X}$ Jakarta [skripsi]. Jurnal Kesehatan Masyarakat Undip; 2017;5(3).

40. Sutrisno dan Kusmawan Ruswandi. Prosedur Keamanan, Keselamatan, \& Kesehatan Kerja. Sukabumi: Yudhistira; 2007.

41. Qomariyatus S. Analisis Sif Kerja Masa Kerja dan Budaya K3 dengan Fungsi Paru Pekerja Tambang Batu Bara pada PT. X Kalimantan Selatan. Banjarmasin: Universitas Lambung Mangkurat; 2014.

42. Yunus F. Dampak Debu Industri Pada Pekerja, FKUI Bagian Pulmonologi FKUI, Unit Paru RSUP Persahabatan. Jakarta: Cermin Dunia Kedokteran; 2006.

43. Lewin K. A Dynamic Theory of Personality. Selected Papers. New York: Mc- Graw Hill; 1970.

44. Dwi Yani Bidaya. Hubungan Tingkat Pengetahuan Ibu Dengan Perilaku Pencegahan ARI Pada Bayi di Puskesmas Kecamatan Segedong [skripsi]. Segedong: Kalimantan Barat; 2012. 